\title{
Karyotype and species diversity of the genus Delomys (Rodentia, Cricetidae) in Brazil
}

\author{
Nilson I. T. ZANCHIN, Ives J. SBALQUEIRO, Alfredo LANGGUTH, \\ Renato C. BOSSLE, Elizabeth C. CASTRO, \\ Luiz F. B. OLIVEIRA and Margarete S. MATTEVI
}

Zanchin N. I. T., Sbalqueiro I. J., Langguth A., Bossle R. C., Castro E. C., Oliveira L. F. B. and Mattevi M. S. 1992. Karyotype and species diversity of the genus Delomys (Rodentia, Cricetidae) in Brazil. Acta theriol. 37: 163 - 169.

Cytogenetic analyses were performed in 39 specimens of Delomys trapped in six localities distributed along the Atlantic forest range of the genus. Only two karyotypic forms were found: $2 \mathrm{n}=72, \mathrm{FN}=90$ to the north and $2 \mathrm{n}=82, \mathrm{FN}=80$ to the south, with an overlapping area in São Paulo and Paraná states. No hybrids were found and given the large difference in karyotype it is likely that any hybrids produced would be infertile. Based on the skin coloration and type localities of the species described it is suggested that the $2 \mathrm{n}=72$ taxon corresponds to Delomys sublineatus and the $2 \mathrm{n}$ $=82$ form to $D$. dorsalis.

Departamento de Genética, Universidade Federal do Rio Grande do Sul, C. P. 15053, 91501 Porto Alegre, RS (NITZ, ECC, LFBO, MSM); Departamento de Genética, Universidade Federal do Paraná, Curitiba (IJS, RCB); Museu Nacional, Rio de Janeiro (AL), Brazil. Reprint request should be addressed to MSM

Key words: Delomys, karyotypes

\section{Introduction}

The genus Delomys was proposed to include two species of Thomasomys from the southeast coast of Brazil: T. sublineatus and T. dorsalis, the latter incorporating the subspecies collinus (Thomas 1917). Ellerman (1941) questioned the status of this genus, considering it to be no more than a species group within Thomasomys. This opinion was followed by Moojen (1952), Cabrera (1961), and Honacki et al. (1982). Nevertheless, Avila Pires (19j0a, b) and Reig $(1981,1984)$ believe that Delomys is a valid genus. Avila Pires $(1960 \mathrm{a}, \mathrm{b})$ suggested the following nominal forms: $D$. dorsalis (type locality: Rio Grande do Sul), D. collinus (type locality: Itatiaia, Rio de Janeiro), D. sublineatus (type locality: Engenheiro Reeve, Espírito Santo) and D. peblejus, based on an incomplete fossil skull of a young animal collected in Lagoa Santa (Minas Gerais, Central Brazil). Hesperomys sub- 
flavus Wagner, included in Delomys by Tate (1932), belongs to Oryzomys according to most modern authors (Cabrera 1961, Honacki et al. 1982, A. Langguth, unpubl. data). Hesperomys dorsalis obscura Leche from Taquara do Mundo Novo, RS is probably the same as $D$. dorsalis (Gyldenstolpe 1932). Cabrera (1961) and Honacki et al. (1982) recognize only one species of Delomys, $D$. dorsalis, which includes the subspecies collinus and sublineatus. Thus, the genus Delomys is variably considered as including one, two or three living species, and the validity of the genus itself is questioned.

Specimens of Delomys dorsalis (2 males and 2 females referred to "Thomasomys") studied by Yonenega (1975) and of D. sublineatus (named "Thomasomys sp.") investigated by Kasahara and Yonenaga-Yassuda (1984), from Casa Grande, near Salesópolis, São Paulo, had diploid numbers (2n) of 82 and 72 respectively.

The genus has been recorded in the Atlantic Forest of Brazil between $20^{\circ}$ and $30^{\circ} \mathrm{S}$ latitude, and Massoia (1962) reported $D$. dorsalis as far west as Misiones in Argentina. In this paper, we report additional cytogenetic data from 39 specimens

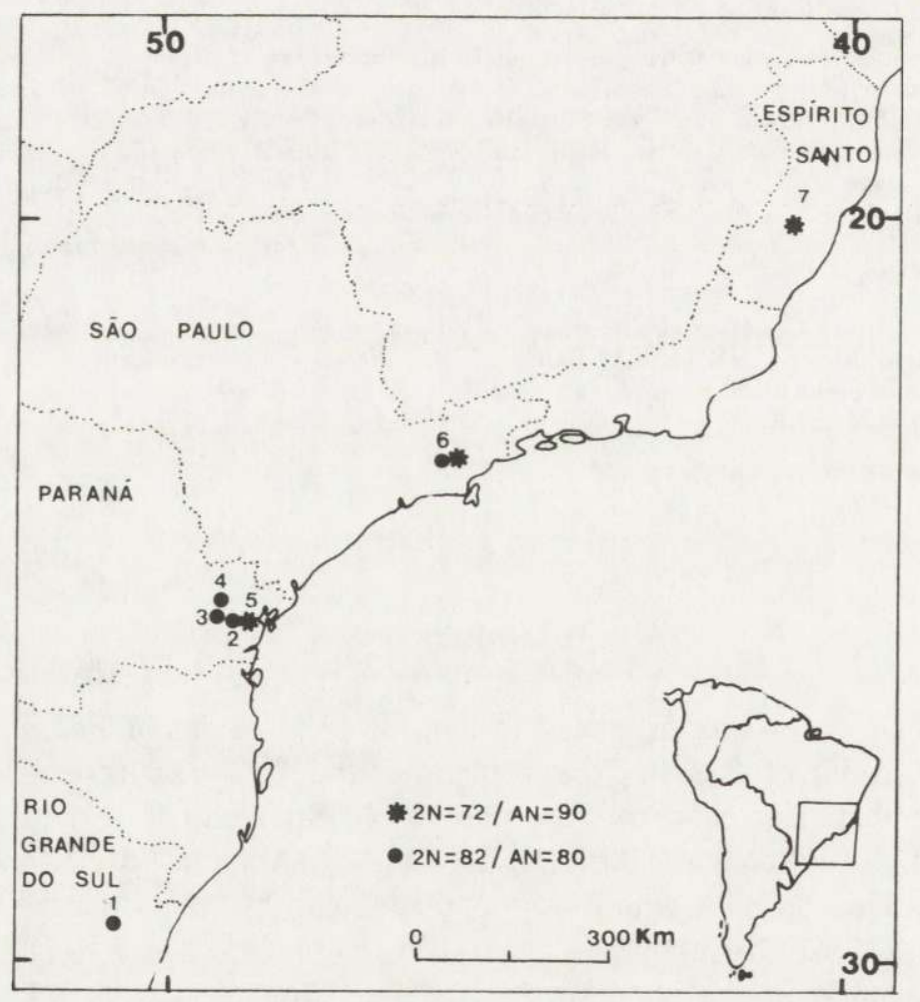

Fig. 1. Collection points of Delomys. 1. Sapiranga (Rio Grande do Sul state), $2 n=82, F N=80.2 .3$. and 4. Piraquara, Morretes, and Quatro Barras (Paraná state), $2 n=82, F N=80.5$. Antonina (Paraná state), $2 n=72, F N=90.6$. Casa Grande (São Paulo state), $2 n=72, F N=90$ and $2 n=82, F N=80$ (Yonenaga 1975, Kasahara and Yonenaga-Yassuda 1984). 7. Monte Verde (Espírito Santo state), $2 \mathrm{n}=72, \mathrm{FN}=90$. 
of Delomys representative of the whole Atlantic Forest range of the genus including, for the first time, modern banding techniques. The results suggest that the genus consists of a northern taxon $(2 n=72)$ and a southern one $(2 n=82)$.

\section{Materials and methods}

Mitotic preparations were made by the technique of Baker et al. (1982). G- and C-bands were obtained by the Seabright (1971) and Sumner (1972) methods, respectively. Sample sizes and geographical locations of the specimens analysed are given in Table 1 and Figure 1.

Table 1. Localities, species, number of males and females analysed and diploid (2n) and fundamental (FN) numbers observed.

\begin{tabular}{|c|c|c|c|c|}
\hline \multirow{2}{*}{ Locality and species } & \multicolumn{2}{|c|}{ Number studied } & \multirow{2}{*}{$2 n$} & \multirow{2}{*}{ FN } \\
\hline & Males & Females & & \\
\hline \multicolumn{5}{|l|}{ D. dorsalis } \\
\hline 1. Sapiranga, RS, $29^{\circ} 35^{\prime} \mathrm{S}, 51^{\circ} 02^{\prime} \mathrm{W}$ & 1 & 2 & 82 & 80 \\
\hline 2. Piraquara, $\mathrm{PR}, 25^{\circ} 25^{\prime} \mathrm{S}, 48^{\circ} 55^{\prime} \mathrm{W}$ & 3 & - & 82 & 80 \\
\hline 3. Morretes, $\mathrm{PR}, 25^{\circ} 25^{\prime} \mathrm{S}, 48^{\circ} 59^{\prime} \mathrm{W}$ & 7 & 5 & 82 & 80 \\
\hline 4. Quatro Barras, PR, $25^{\circ} 20^{\prime} \mathrm{S}, 48^{\circ} 50^{\prime} \mathrm{W}$ & 1 & 1 & 82 & 80 \\
\hline \multicolumn{5}{|l|}{ D. sublineatus } \\
\hline 5. Antonina, $\mathrm{PR}, 25^{\circ} 15^{\prime} \mathrm{S}, 49^{\circ} 15^{\prime} \mathrm{W}$ & - & 1 & 72 & 90 \\
\hline 7. Monte Verde, ES, $19^{\circ} 53^{\prime} \mathrm{S}, 41^{\circ} 57^{\prime} \mathrm{W}$ & 15 & 3 & 72 & 90 \\
\hline
\end{tabular}

Numbers correspond to those of Figure 1. Site number 6 was assigned to the locality of Casa Grande, the collecting site of Yonenaga (1975) and Kasahara and YonenagaYassuda (1984). RS, PR, and ES refer to Rio Grande do Sul, Paraná, and Espiríto Santo states, respectively.

Skins and skulls of the specimens karyotyped were deposited in the following Brazilian institutions: material from Espírito Santo in Departamento de Sistemática e Ecologia, Universidade Federal da Parába in João Pessoa; specimens from Rio Grande do Sul and from Piraquara are kept at the Departamento de Genética, Universidade Federal do Rio Grande do Sul in Porto Alegre; all other specimens from Paraná are kept at the Museu de História Natural "Capão da Imbuia” in Curitiba.

\section{Results}

Nineteen specimens (localities $1-4$ ) of $D$. sublineatus had a diploid number (2n) of 72 and a fundamental number (FN) of 90 (Fig. 2A). The autosomes comprise three pairs of large submetacentrics, seven pairs of metacentrics to submetacentrics decreasing gradually from medium to small, and 24 pairs of acrocentrics varying from large to small size. The $\mathrm{X}$ is a large submetacentric chromosome and the $\mathrm{Y}$ is a small acrocentric. Constitutive heterochromatin (C-bands) is absent 


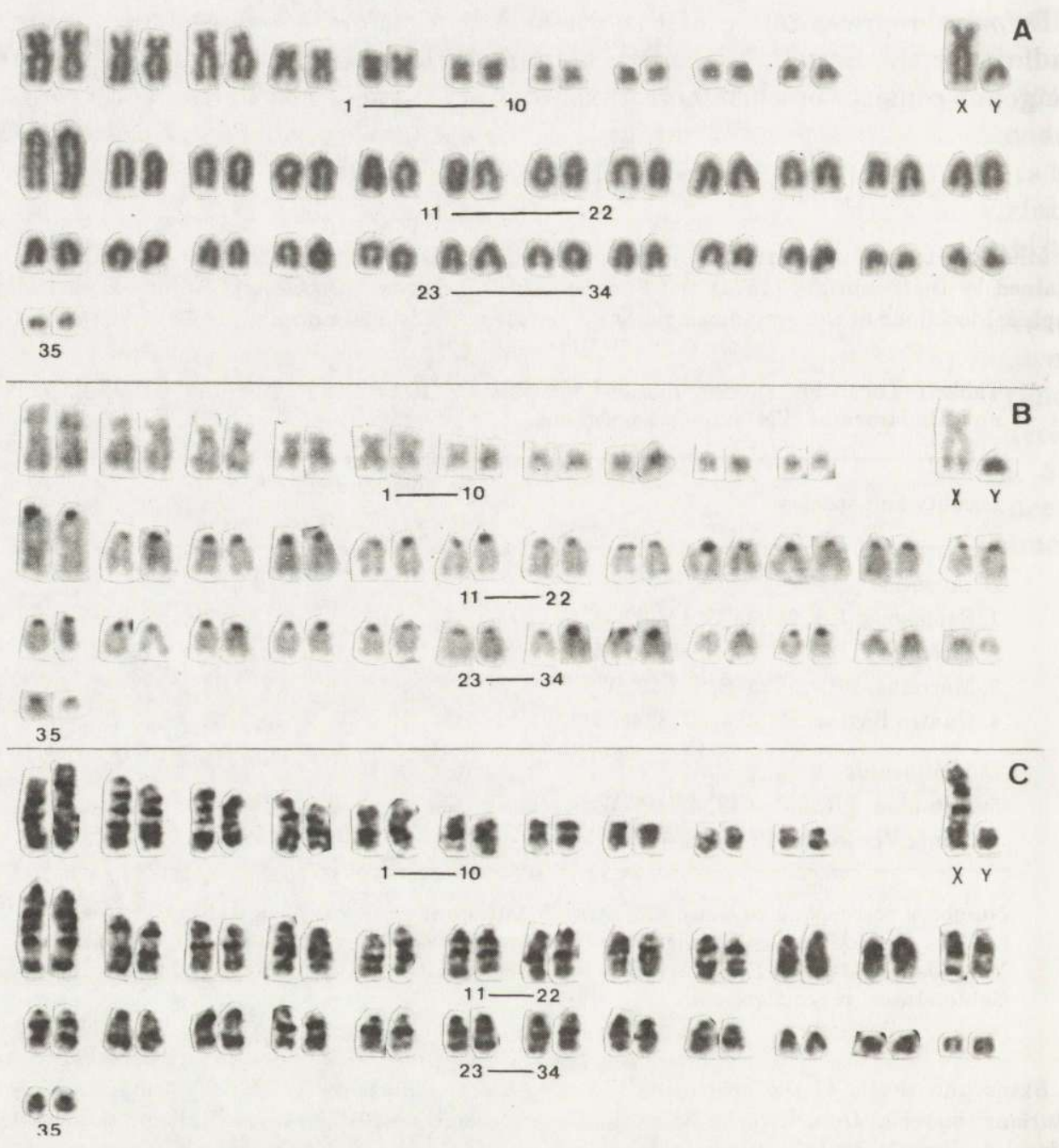

Fig. 2. A - Delomys sublineatus, male, Giemsa staining; B - male, C-banding; C-male, G-banding.

from the three large and one medium submetacentric and occurs as small blocks in the remaining biarmed pairs (Fig. 2B). It is present in the pericentromeric regions of the acrocentric pairs, and of the $\mathrm{X}$ chromosome. The long arm of the $\mathrm{Y}$ is totally heterochromatic. Fig. $2 \mathrm{C}$ presents the G-bands pattern of this karyotype.

A $2 \mathrm{n}=82, \quad \mathrm{FN}=80$ karyotype was found in 20 specimens (localities 5,7 ) of D. dorsalis (Fig. 3A). All the autosomes are acrocentric with a gradual variation in size. The $\mathrm{X}$ chromosome is a large submetacentric and the $\mathrm{Y}$ is the smallest acrocentric of the karyotype. The constitutive heterochromatin occurs at the 


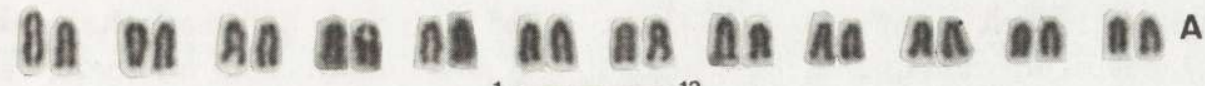

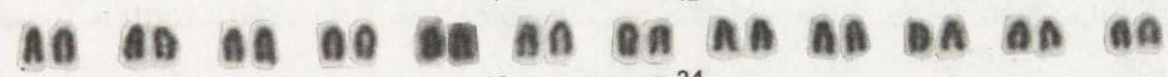

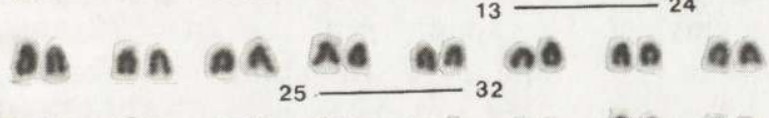

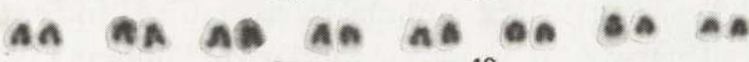

$33 \stackrel{40}{4} 40$

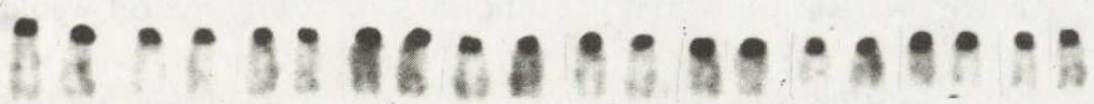

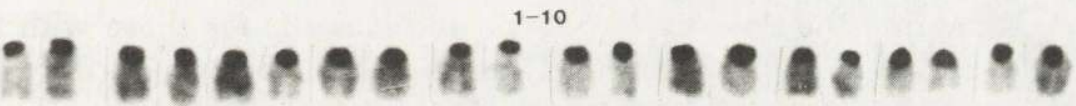

$11-20$

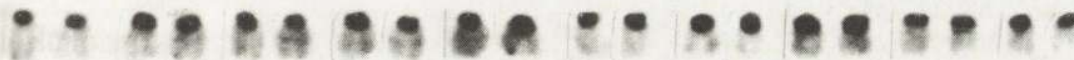

21-30

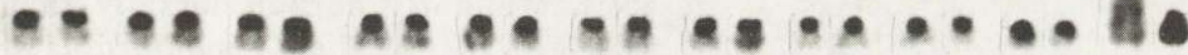

$31-40$

$x$
$x$

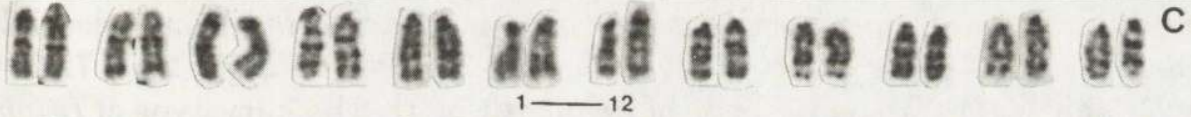

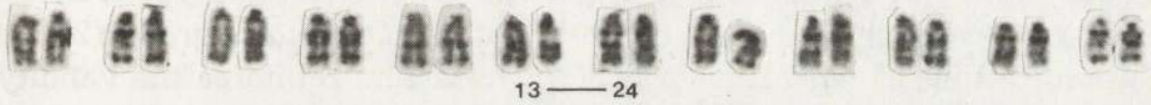

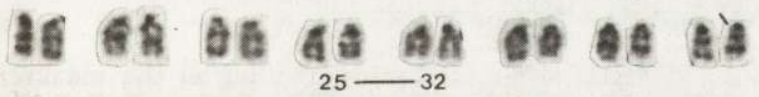

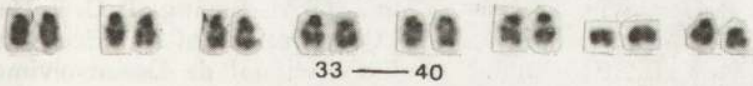

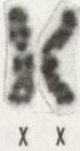

Fig. 3. A - Delomys dorsalis, female, Giemsa staining; B - male, C-banding; C - female, G-banding.

pericentromeric regions of all autosomes, and of the $\mathrm{X}$ chromosome. The long arm of the $\mathrm{Y}$ is heterochromatic (Fig. 3B). G-bands are shown in Fig. 3C.

\section{Discussion}

The collection points for this study span virtually the whole range of the genus Delomys (Fig. 1). Only two karyotypic forms were found: $2 \mathrm{n}=72, \mathrm{FN}=90$ at north (from Espírito Santo to Paraná states) and $2 \mathrm{n}=82, \mathrm{FN}=80$, at south (from 
São Paulo to Rio Grande do Sul). These forms overlap around São Paulo and Paraná. Although comparison of the G-band patterns between these two karyotypes is difficult due to their high diploid and fundamental numbers, very few elements seem to be shared by them. This mean that not only centric fusions but pericentromeric inversions and/or other complex rearrangements are responsible for the different karyotypes. The simpatry of the $2 n=72$ and 82 animals of Casa Grande, São Paulo (Yonenaga 1975, Kasahara and YonenagaYassuda 1984), suggests that these entities are unable to hybridize, indicating that Delomys may consist of only two species in agreement with Thomas (1917). The large difference between the karyotypes indicates that any hybrid would be infertile.

Among the names available for species of Delomys we have chosen sublineatus for the animals bearing the $2 n=72$ karyotype and dorsalis for those with $2 n=$ 82 , because all specimens collected in Rio Grande do Sul, the type locality of $D$. dorsalis, have $2 \mathrm{n}=82$ and all animals from Espírito Santo, collected near the type locality of $D$. sublineatus, have $2 \mathrm{n}=72$.

It is difficult to identify the two species on the basis of the cranial morphology alone. The skin, however, is different, and corresponds to the original description given for the type species. $D$. dorsalis is slightly darker dorsally than $D$. sublineatus. Ventrally $D$. dorsalis is mouse-grey, darker than $D$. sublineatus which shows a bright yellow-reddish (buffy) band on the side, absent in the former.

The differences observed between Delomys and Thomasomys include diploid number ( $2 \mathrm{n}=42-44$ for Thomasomys, Gardner and Patton 1976; $2 \mathrm{n}=72,82$ for Delomys), shape of palate, and shape of zygomatic plate. The karyotype of Delomys $(2 \mathrm{n}=82)$ is more similar to that of Oryzomys of the O. nitidus group $(2 \mathrm{n}=80$, FN $=86$ ) than to that of Thomasomys. These characters reinforce the validity of Delomys as a separate genus, that includes two species.

Acknowledgements: We are grateful to F. M. Salzano for his critical reading of the manuscript. Thanks are due to B. Erdtmann, M. W. P. Carvalho, J. F. de S. Lima, C. M. Boeing, T. C. P. Cesar, and M. B. Lange for their help in the field work. Grants from the Organization of American States (OAS), Financiadora de Estudos e Projetos (FINEP), and Conselho Nacional de Desenvolvimento Científico e Tecnológico (CNPq) are also acknowledged.

\section{References}

Avila-Pires F.D. de 1960a. Roedores colecionados na Região de Lagoa Santa, Minas Gerais, Brasil. Arquivos do Museu Nacional, Rio de Janeiro 50: 25 - 45.

Avila-Pires F. D. de 1960b. Um novo genêro de roedor sul-americano. Boletim do Museu Nacional, nova série 220 : $1-6$.

Baker R. J., Haiduk M. W., Robbins L. W., Cadena A. and Koop B.F. 1982. Chromosomal studies of American bats and their systematic implications. [In: Mammalian biology in South America. M. A. Mares and H. H. Genoways, eds]. Special Publications Series, Pymatuning Laboratory of Ecology, University of Pittsburg 6: 1- 539.

Cabrera A. 1961. Catálogo de los mamíferos de América del Sur, II. Revista do Museo Argentino de Ciencias Naturales 4 (2): $309-732$. 
Ellerman J. R. 1941. The families and genera of living rodents. British Museum (Natural History), London 2: xii+ $1-690$.

Gardner A. L. and Patton J. L. 1976. Karyotypic variation in Oryzomyine rodents (Cricetidae) with comments on chromosomal evolution in the Neotropical cricetine complex. Occas. Papers Mus. Zool., Louisiana Sate Univ. 9: 1- 48.

Gyldenstolpe N. 1932. A manual of neotropical sigmodont rodents. Kungl Svenska Vetenskapsaakedemiens Handlingar, Tredje Serien 11: 1 - 164.

Honacki J. H., Kinman K. E. and Koeppl J. W. 1982. Mammal species of the world: a taxonomic and geographic reference. Allen Press, Inc. Assoc. Syst. Coll., Lawrence, Kansas: 1 - 694 .

Kasahara S. and Yonenaga-Yassuda Y. 1984. A progress report of of cytogenetic data on Brazilian rodents. Revista Brasileira de Genética 7: 509 - 533.

Massoia E. 1962. Dos especies de cricetideos nuevas para la Argentina. Physis 23: 27 - 34 .

Moojen J. 1952. Os roedores do Brasil. Instituto Nacional do Livro, Rio de Janeiro: 1 - 214.

Reig O. A. 1981. Teoria del origen y desarrollo de la fauna de mamiferos de América del Sur. Monagraphiae Naturae, Museo Municipal de Ciencias Naturales “Lorenzo Scaglia" 1: 1-161.

Reig O. A. 1984. Distribuição geográfica e história evolutiva dos muróides sul- americanos (Cricetidae, Sigmodontinae). Revista Brasileira de Genética 7: 333 - 365.

Seabright M. 1971. A rapid banding technique for human chromosomes. Lancet 2: $971-972$.

Sumner A. T. 1972. A simple technique for demonstrating centromeric heterochromatin. Exptl. Cell Res. 75: $304-306$.

Tate G. H. H. 1932. The taxonomic history of the South and Central American oryzomyine genera of rodents (excluding Oryzomys): Nesoryzomys, Zygodontomys, Chilomys, Delomys, Phaenomys, Rhagomys, Rhipidomys, Nyctomys, Oecomys, Thomasomys, Inomys, Aepeomys, Neacomys and Scolomys. Amer. Mus. Novitates 581: $1-28$.

Thomas O. 1917. On the arrangement of the South American rats allied to Oryzomys and Rhipidomys. Annals and Magazine of Natural History, Series 18, 20: 192 - 198.

Yonenaga Y. 1975. Karyotypes and chromosome polymorphism in Brazilian rodents. Caryologia 28: $269-286$.

Received 10 October 1991, accepted 3 April 1992. 